IRA-International Journal of Management \& Social Sciences

ISSN 2455-2267; Vol.03, Issue 03 (2016)

Institute of Research Advances

http://research-advances.org/index.php/RAJMSS

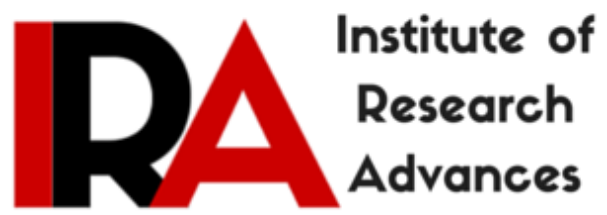

\title{
Proto-historic Copper Tools in Rajasthan: An Overview
}

\section{Dr. Ambika Dhaka}

Assistant Professor, Dept. of History, Maharaja Ganga Singh University, Bikaner-334004, India.

DOI: http://dx.doi.org/10.21013/jmss.v3.n3.p19

\section{How to cite this paper:}

Dhaka, D. (2016). Proto-historic Copper Tools in Rajasthan: An Overview. IRAInternational Journal of Management \& Social Sciences (ISSN 2455-2267), 3(3). doi:http://dx.doi.org/10.21013/jmss.v3.n3.p19

(C) Institute of Research Advances

\section{(cc) BY-NO}

This works is licensed under a Creative Commons Attribution-Non Commercial 4.0 International License subject to proper citation to the publication source of the work.

Disclaimer: The scholarly papers as reviewed and published by the Institute of Research Advances (IRA) are the views and opinions of their respective authors and are not the views or opinions of the IRA. The IRA disclaims of any harm or loss caused due to the published content to any party. 


\section{Introduction:}

The discovery of metal technology has been a turning point in bringing about a revolutionary change in the living pattern of human race. Certain historical periods got identified with names of metals as prefix signifying the technological know-how of the people. The earliest features of urban life in Indian subcontinent are indebted to Harappan legacy who were skilled in making implements of copper and its alloys. Apart from Harappans, some other cultures also flourished which were either contemporary or later to Harappans. Here, a mention may be made of Chalcolithic Cultures and Copper Hoards Culture located in north, central and western parts of India. The problem of Copper Hoards Culture is still an unresolved issue and a matter of debate among archaeologists. The distinct and unique tool typology of Copper Hoards from Rajasthan is noteworthy in comparison to its counterpart in Gangetic Valley. Copper objects like anthropomorphs, tanged khurpis, shouldered axes, lugged celts etc. are characteristics of Gangetic valley which are conspicuous by their absence in Rajasthan.

\section{Copper Hoards and Copper Objects in Rajasthan:}

Some recent finds of copper hoards and copper objects in the past few decades in Rajasthan have brought about remarkable change in the conventional opinion of archaeologists and historians. The famine relief programmes by government machinery have transformed into boom for Copper Hoard Culture in the state since a great number of them have come up during execution of such projects. Most of the Copper Hoards revealed so far, have come up in isolation indicating that they were perhaps hidden treasure for adverse times or concealed for fear of burglary etc. At present, more than two dozen sites of copper hoards and copper objects are known from Rajasthan which signify its extensive use. In the purview of the ancient copper metallurgical sites in the pockets of Aravallis and other areas lying in its vicinity, the possibilities of untapped potential in the form of new copper hoard sites cannot be ignored. Some significant copper hoard sites are Ganeshwar (Agrawal, 1978) (distt. Sikar), Chithwari (Singh, 1993) (distt.Jaipur), Medh(distt. Jaipur), Nandalalpura(distt. Jaipur), Karera Bujarg and Sakatpura (Dhaka, 2005-06) (distt. Tonk), Kota Maholi (distt. Sawai Madhopur), Mallaha (Departmental Activities, 1996-97) (distt. Bharatpur), Balambasai \& Dantia (distt. Alwar), Varman (Dhaka, 2002) (distt. Sirohi), Bhandar (Dhaka, 2002-03) (distt. Pali), Sabaniya (Bikaner) etc. A large variety of copper objects are reported from these sites like flat celts, bar celts, rings, bangles, arrow-heads, fish-hooks, harpoons, choppers, chisels etc. Of these, chopper is an important Protohistoric copper implement which has been reported from Kalibanga, Ahar (Sankalia, 1961-62), Kurada (Agrawala, 1984-85), Chithwari (Singh et al., 1993 a,b), Namana (Rajasthan Patrika1996, April 5), Balathal (Mishra, 2007), Ojhiyana (Mishra et al., 2007 a,b) and Ganeshwar. Since it has been reported in proper context from regular excavation sites, its period may be assigned to first quarter of $3^{\text {rd }}$ millennium B.C. The excavations at Harappa had revealed damaged chopper implement from early levels. The fragments of six choppers from Chithwari bear close affinity with the ones from Kurada. These were found in an earthen pot buried under the earth. A fragment of chopper and a mini chopper in two pieces from Protohistoric site Namana is in the custody of Government Museum, Kota and registered against the serial number 272 and 273. The copper metal show-case in Government Museum, Ahar, has chopper implements displayed in it. The chopper has also been reported from Ojhiyana in excavations. Similar chopper implements have also been found at Mitathal and Balathal. Presently, we find this implement as an important feature of agricultural activity in rural India and is used to chop fodder for animals and similar other works. This is an important paradigm of transmission of technical know-how across centuries. 
Copper celt is one such implement which has been commonly found in the hoards from Rajasthan. These celts are either flat or bar like in shape. One of the largest copper hoard of flat celts has was reported from Ganeshwar (Kumar, 1984-85) and presently in Government Museum, Sikar. Agrawal and Kumar opine that cire-purdue technology was involved in their making. However, the author of this paper holds a different opinion. When we observe the sides of these celts minutely, we find some scrapped marks on it. On this basis we may conclude that instead of cire-purdue process, a different method was applied in casting these celts. It is quite possible that the casting mould comprised of two parts i.e lower and upper. The final products cast by these moulds had a slightly raised edge which was shaped by some lathe kind of a machine under certain temperature.

One of the exceptional feature on Ganeshwar Copper Hoard celts is round indentation marks which varied in group numbers from two to sixteen. Various scholars interpreted them differently. According to R.C. Agrawal and V. Kumar, the round indentation marks noticed on top of 50 heavy flat celts from Ganeshwar represent job symbols of copper smiths who manufactured them and on this basis they received their remuneration from merchants. K.K. Thaplyal and S.P. Shukla have opined that they probably served as trade-marks of the artisans who manufactured them. However, D.P. Agrawal considers them as units of weights for smiths. When one visualises the things rationally, one finds that as far as the identification of indentation marks with job symbols is concerned, it does not seem probable. Firstly, the symbol grouping is more than two dozen which implies that thirty groups of smiths were working at Ganeshwar. Secondly, the smelting area at Ganeshwar is quite limited to accommodate this large number for processing of copper. Out of six bar celts from Sakatpura Copper Hoard, three bar celts bear indentation marks near the butt end. If we consider the hypothesis of D.P. Agrawal, these celts should have similar weights. On the contrary, we find remarkable variation in the weights. So it is hard to accept them as weight symbols. The round indentation marks have come to light from Ganeshwar, Kurada, Sakatpura, Dantia and Varman. This pattern of round indentation marks on the celts had been observed outside Rajasthan as well. Five celts from Navdatoli (Maharashtra) have yielded circular indentation marks. Since these shallow circular impressions on celts are free from cracks, technically it implies that the smiths raised the temperature of the object before imprinting it. A peculiar graffiti mark with three barbed lines on a flat celt from Varman is noteworthy. This pattern had also been observed on a terracotta from Lal Quila(New Delhi) and one from Rojdi.

The Protohistoric people in Rajasthan were not only involved in giving shape to copper but they also collected the purified metal in the form of ingots. Copper ingots had come to light from Harappan sites as well. Three copper ingots from Mohenjodaro, a bun shaped ingot from Lothal (with 99.81\% copper) and copper ingots from Harappan levels of Chanhudaro are just to name a few. A large number of copper and bronze ingots from Susa, which are displayed in Louvre Museum, bear close affinity with ingots from Lothal and Mohenjodaro. The absence of arsenic in Lothal copper ingots, on the contrary found in Ganeshwar-Khetri Copper belt, suggests that perhaps it was imported from some different source. The Varman Copper Hoard (Sirohi) with three different categories of copper ingots is another remarkable contribution. The copper smiths of Varman were quite intelligent as they cut approximately $1.15 \mathrm{~cm}$ thick copper sheet into three different sizes to serve variable needs and avoid wastage. Some of the Varman copper ingots bear close affinity with Harappan ingots. So is it possible that the copper ingots from this place were being sent to Harappans? 
The Mallah Copper Hoard (Departmental Activities, et al., 1996-97 a, b) site in Rajasthan is significant from the viewpoint of tool typology. This site has yielded harpoons which are unique and distinct in nature from those of Doab region. The harpoons from Mallah exhibit variation in the pattern of barbs with pairs of two, three and four. Another interesting copper object from here is the fragment of shouldered axe which reveals some kind of connectivity with Doab not found elsewhere in Rajasthan. Earlier a river flowed in the proximity of this hoard and presently a locality with the name 'nadia mohallah' clearly supports this fact. It is quite probable that river Ban Ganga previously flowed from here.

Another significant copper hoard is from Samarathpura, distt. Ajmer (Rajasthan). This hoard came to light in course of NREGA project which was being carried out at Undha-Khera in the vicinity of a hillock in 2009. There were fourteen copper celts, lying loose in the soil. But, the State Archaeology \& Museum Deptt., Ajmer, could acquire only nine copper celts. The copper bar celts which have come to light from here are the heaviest one known so far, with some weighing four kilogram and above. The copper bar celts are in good state of preservation and devoid of any indentation marks. Samarathpura lies in the mid of Ganeshwar-Khetri copper belt in north-east and Rajpur Dariba, Ambamata mining zone which includes Ahar or ancient Tambavati in south-west. in this way, the Samarathpura Copper Hoard holds significance in the light of Ahar Culture remains which had been noticed earlier from Kotra (Dainik Bhaskar 1998, 9 July) Protohistoric site in the suburbs of Ajmer City. The Samarathpura copper bar celts bear affinity with the ones from Nandalalpura. However, they are heavier than latter.

\section{Conclusion:}

The Protohistoric people in Rajasthan were quite advanced in using copper technology. They were quite aware of different processes like melting, annealing, close mould casting, use of lathe or cutting machine etc. The copper objects from Rajasthan are quite distinct in tool typology which reflects regional taste. The choppers found at a number of places in Rajasthan are yet unknown to Doab. While the anthropomorphic figures and lugged celts from Doab are conspicuous by their absence in Rajasthan. Besides, the harpoons from Rajasthan are quite different from the ones known from Doab. Technologically, the copper smiths of Rajasthan excelled every bench-mark in processing copper but the issues like assigning any date to Copper Hoards Culture or why they are found in caches and why we fail to find some concrete habitational evidences with this culture are questions which still remain unanswerable.

\section{References:}

Agrawala, R.C.(1978), Copper Celts and Indus Arrow Head from Kulhade ka Johad, District Sikar, Rajasthan, Man and Environment, Vol. II, Ahmedabad, P. 123.

Singh, Harphool (1993), Copper Hoard- An Unpublished Find from Chithwari, Chomu (Jaipur), Tulsi-Pragya, Jaina Vishva Bharati Institute Research Journal, Vol. XVIII, No.4, P.141-143.

Dhaka, Ambika (2005-06), New Copper Hoards from Rajasthan, Puratattva, No.36, New Delhi, P.272-275 \& Plates.

Other Important Discoveries (1982-83), Departmental Activities, The Researcher- A Bulletin of Rajasthan's Archaeology \& Museums, Vol. XVIII, Jaipur, P.137. 
Dhaka, Ambika (2002), Unpublished Copper Hoard From Varman, District Sirohi, Sharma K.G. \& Mehta (Eds.); Nucleus, An Interdisciplinary Journal of Humanities \& Social Sciences, Vol.II, Jaipur, No.2, P.121-128 \& Plates.

Dhaka, Ambika (2002-03), Unpublished Copper Hoard From Bhandar, District Pali, Puratattva, No.33, New Delhi, P.127-130 \& Plates.

Sankalia, H.D (1961-62), Beginnings of Civilization in Rajasthan, The Researcher- A Bulletin of Rajasthan's Archaeology \& Museums, Vol. I, Jaipur, P.4-15.

Agrawala, R.C.(1984-85), Proto-Historic Copper Bowls From Rajasthan, The Researcher- A Bulletin of Rajasthan's Archaeology \& Museums, Vol. XIV-XV, Jaipur, P.1-3 \& Plates.

(1996, April 5), Rajasthan Patrika- A daily Hindi Newspaper, Rajasthan Patrika Press, Kesargarh, Jaipur,P.7.

Mishra, V.N. (2007), Rajasthan: Prehistoric and Early Historic Foundations, Aryan Books International, New Delhi, P.76.

Kumar, Vijay (1984-85), Ganeshwar- Jodhpura Culture- The Antecedents of Copper Age in India, The Researcher- A Bulletin of Rajasthan's Archaeology \& Museums, Vol. XIV-XV, Jaipur, P.5-15 \& Plates.

(1998, July 9), Dainik Bhaskar. Ajmer edn. P.14. 


\section{PLATES:}

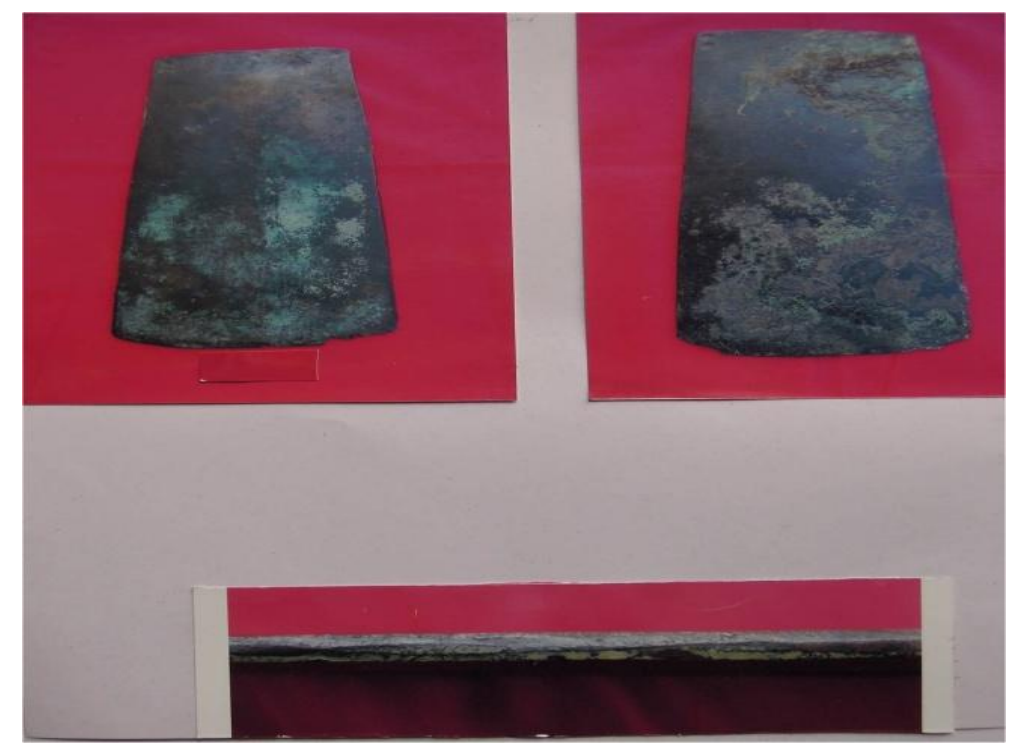

Pl.I: Copper Celts from Ganeshwar along with side view of celt (Sikar).

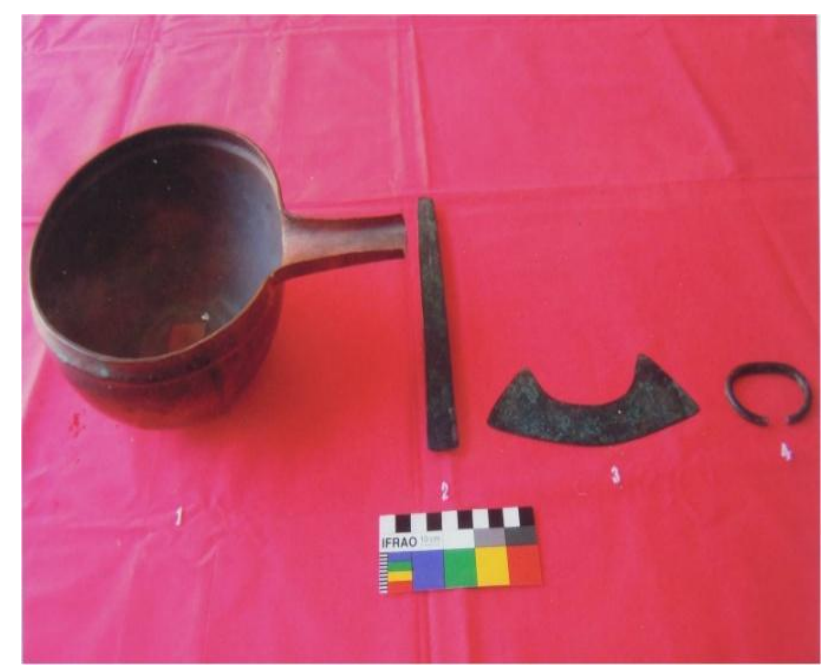

PI.II: Copper Hoard from Kurada (Nagaur) 


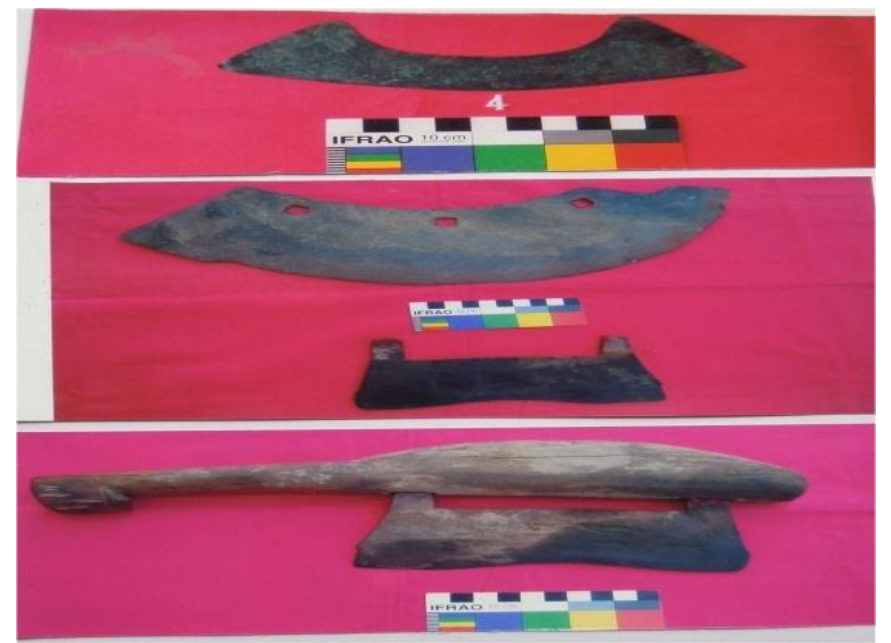

PI.III: Chopper made of Copper from Kurada (above) $\&$ Iron Choppers of $2^{\text {th }}$ cent. from Sikar(below)

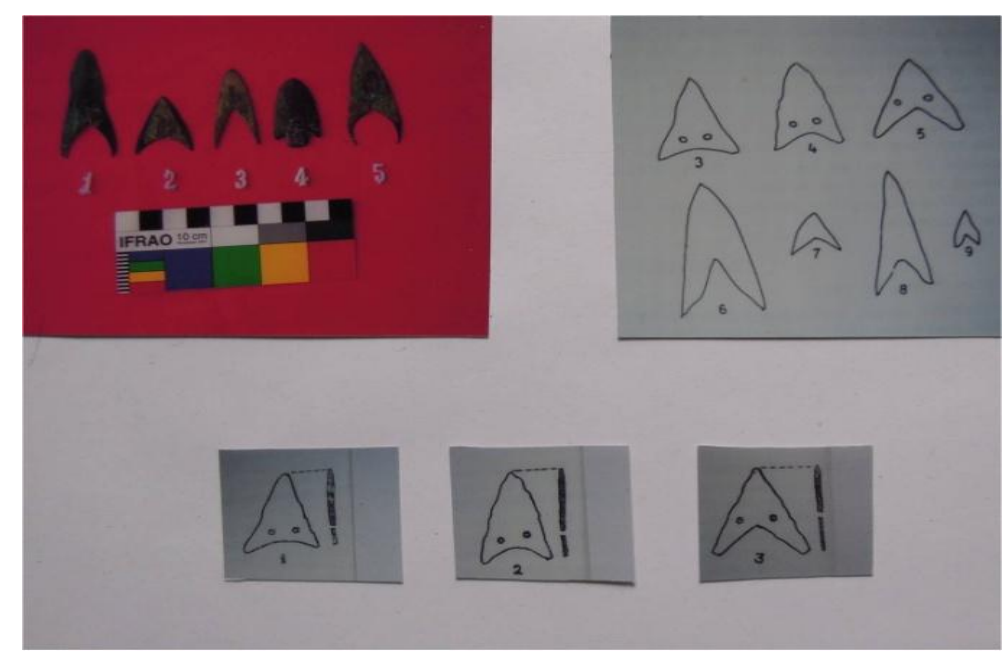

PI.IV: Copper Arrow Heads from Ganeshwar (A), Harappa(B) \& Bagor (C). 


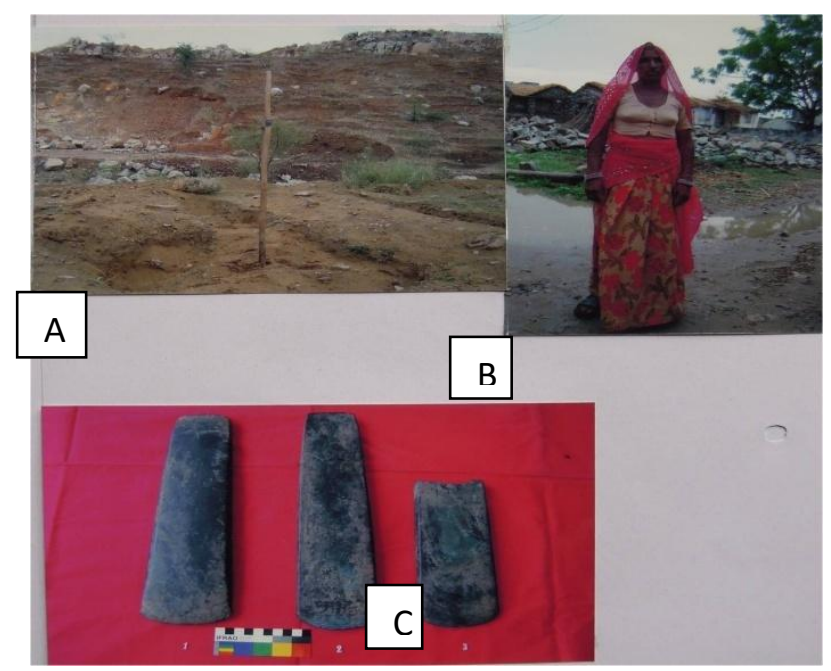

Pl.V: (A) Samarathpura Copper Hoard;(B) Finder of Copper Hoard

(C) Copper Celts.

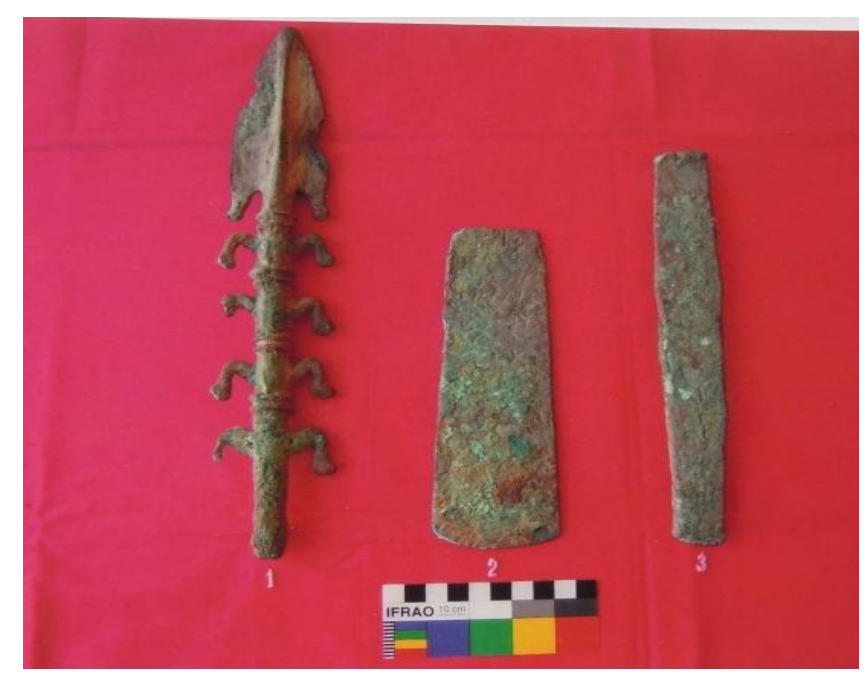

PI.VI: Mallaha Copper Hoard (1)Harpoon, (2) Bar Celt, (3) Chisel. 


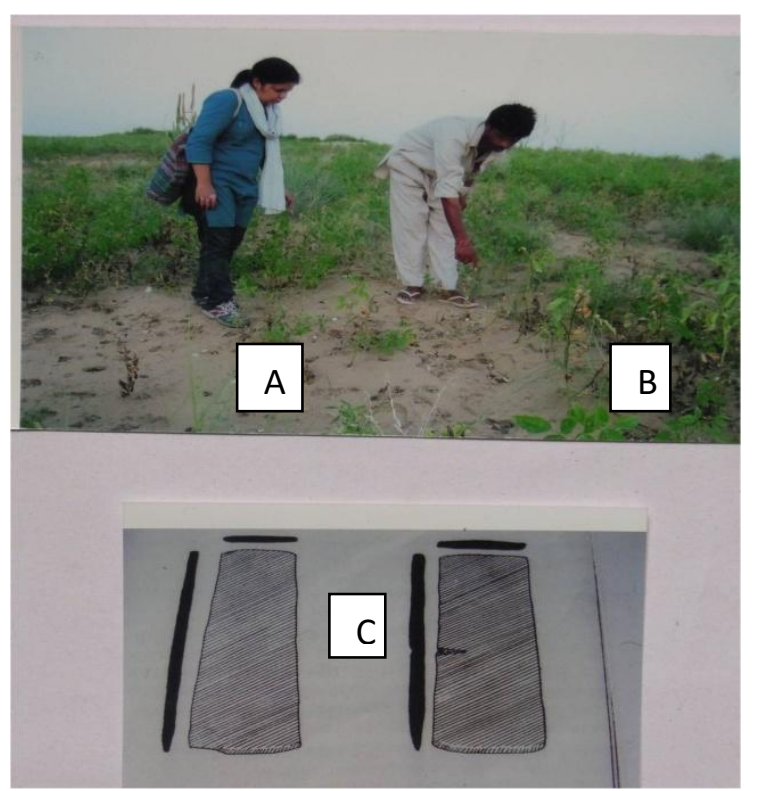

PI.VII: Sabaniya Copper Hoard showing find spot \& copper celts.

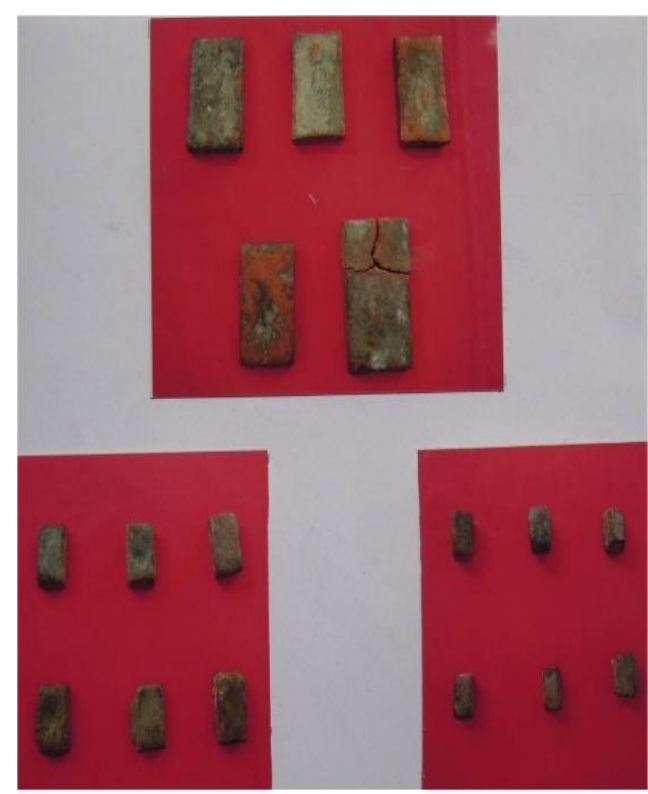

PI.VIII: Copper Ingots from Varman in different different sizes. 